April 2008

\title{
A distinct role for B1b lymphocytes in T cell-independent immunity
}

Kishore R. Alugupalli

Thomas Jefferson University

Follow this and additional works at: https://jdc.jefferson.edu/mifp

Part of the Medical Genetics Commons

Let us know how access to this document benefits you

\section{Recommended Citation}

Alugupalli, Kishore R., "A distinct role for B1b lymphocytes in T cell-independent immunity" (2008). Department of Microbiology and Immunology Faculty Papers. Paper 3.

https://jdc.jefferson.edu/mifp/3

This Article is brought to you for free and open access by the Jefferson Digital Commons. The Jefferson Digital Commons is a service of Thomas Jefferson University's Center for Teaching and Learning (CTL). The Commons is a showcase for Jefferson books and journals, peer-reviewed scholarly publications, unique historical collections from the University archives, and teaching tools. The Jefferson Digital Commons allows researchers and interested readers anywhere in the world to learn about and keep up to date with Jefferson scholarship. This article has been accepted for inclusion in Department of Microbiology and Immunology Faculty Papers by an authorized administrator of the Jefferson Digital Commons. For more information, please contact: JeffersonDigitalCommons@jefferson.edu. 
A distinct role for B1b lymphocytes in $\mathrm{T}$ cell-independent immunity

\section{Kishore R. Alugupalli}

Department of Microbiology \& Immunology and Kimmel Cancer Center, Thomas Jefferson University, Philadelphia, PA 19107

Correspondence: Kishore R. Alugupalli, Department of Microbiology and Immunology, Kimmel Cancer Center, Thomas Jefferson University, 233 south $10^{\text {th }}$ Street, BLSB 726, Philadelphia, PA 19107. Phone: 1-215-503-4554; Fax: 1-215-923-4153; Email: kishore.alugupalli@mail.jci.tju.edu 


\section{Table of contents}

$1 \quad$ Introduction................................................................. 5

2 T cell-dependent and -independent antigens................................... 5

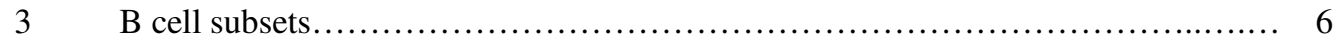

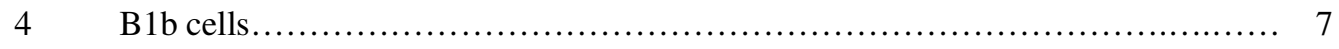

$5 \quad$ Role of B1b cells in T cell-independent responses............................. 8

$5.1 \quad$ Immunity to Borrelia hermsii.................................................. 8

5.2 Immunity to Streptococcus pneumoniae................................... 11

5.3 Response to NP-Ficoll, a model TI-2 antigen.............................. 13

6 Activation of antigen-specific T cell-independent B cells....................... 14

6.1 Role of Btk in T cell-independent B cell responses........................... 15

6.2 Role of co-stimulatory signals in T cell-independent B cell responses............. 16

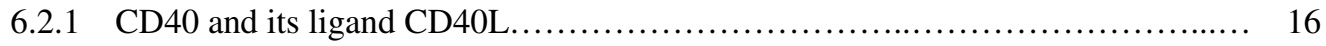

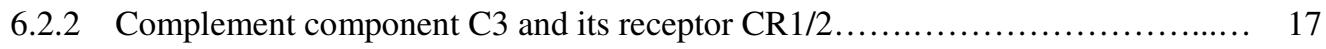

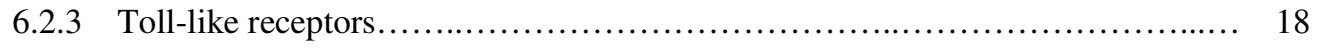

$7 \quad$ Impaired T cell-independent B cell responses.................................... 20

$8 \quad$ Memory B1b cells........................................................... 21

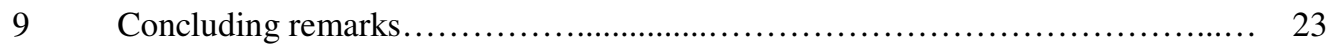

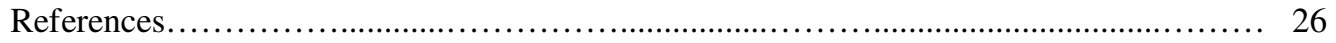




$\begin{array}{ll}\text { Abbreviations } \\ \text { AID } & \text { Activation-induced cytidinedeaminase } \\ \text { BCR } & \text { B cell antigen receptor } \\ \text { Btk } & \text { Bruton's tyrosine kinase } \\ \text { CSR } & \text { Class switch-recombination } \\ \text { FO } & \text { Follicular } \\ \text { LPS } & \text { Lipopolysaccharide } \\ \text { MZ } & \text { Marginal zone } \\ \text { NP } & \text { 4-Hydroxy-3-Nitrophenyl-Acetyl } \\ \text { PerC } & \text { Peritoneal cavity } \\ \text { PS } & \text { Polysaccharide } \\ \text { Rag1 } & \text { Recombination-activating gene 1 } \\ \text { SHM } & \text { Somatic hypermutation } \\ \text { TD } & \text { T cell-dependent } \\ \text { TI } & \text { T cell-independent } \\ \text { TI-1 } & \text { T cell-independent type 1 } \\ \text { TI-2 } & \text { T cell-independent type 2 } \\ \text { TLR } & \text { Toll-like receptor } \\ \text { Xid } & \text { X-linked immunodeficiency } \\ \text { XLA } & \text { X-linked agammaglobulinemia } \\ & \end{array}$




\begin{abstract}
Pathogenesis of infectious disease is not only determined by the virulence of the microbe but also by the immune status of the host. Vaccination is the most effective means to control infectious diseases. A hallmark of the adaptive immune system is the generation of B cell memory, which provides a long-lasting protective antibody response that is central to the concept of vaccination. Recent studies revealed a distinct function for B1b lymphocytes, a minor subset of mature B cells that closely resembles that of memory B cells in a number of aspects. In contrast to the development of conventional B cell memory, which requires the formation of germinal centers and $\mathrm{T}$ cells, the development of B1b cell-mediated long-lasting antibody responses occurs independent of T cell-help. T cell-independent (TI) antigens are important virulence factors expressed by a number of bacterial pathogens including those associated with biological threats. TI antigens cannot be processed and presented to $\mathrm{T}$ cells and therefore are known to possess restricted T cell-dependent (TD) immunogenicity. Nevertheless, specific recognition of TI antigens by B1b cells and the highly protective antibody responses mounted by them clearly indicate a crucial role for this subset of B cells in the host's ability to overcome the restricted TD antibody response. Understanding the mechanisms of long-term immunity conferred by B1b cells may lead to improving the vaccine efficacy for a variety of TI antigens.
\end{abstract}




\section{Introduction}

Infectious diseases are the leading cause of mortality and morbidity worldwide. The acquisition of virulence-encoding genetic elements by horizontal transfer, the high mutation rates of pathogens, and the emergence of antibiotic resistance make it difficult to control infectious diseases by therapeutic means. Vaccination is the most effective way to control infectious diseases as it induces long-lasting immunity. A hallmark of the adaptive immune system is the development of B cell memory, which provides a protective antibody response upon re-exposure to the same antigen and is central to the concept of vaccination (MacLennan et al., 2000). T cells are crucial for the formation of germinal centers, a specialized microenvironment of the secondary lymphoid organs in which proliferation of antigen-specific B cells, affinity maturation of B cell antigen receptor (BCR) by somatic hypermutation (SHM), and alteration of antibody isotype by class-switch recombination (CSR) occur. The ultimate accomplishment of the germinal center reaction is the development of memory B cells and long-lived plasma cells that generate high affinity antibodies of different Ig isotypes (McHeyzer-Williams et al., 2001;

McHeyzer-Williams, 2003). T cell-independent (TI) antibody responses are highly protective and develop much faster than T cell-dependent (TD) antibody responses (Maizels and Bothwell, 1985; Vos et al., 2000; Martin and Kearney, 2001). In spite of the potential utility of TI responses as a preventive and therapeutic intervention against a wide range of pathogens, little work has been done in this area. One reason is that, until recently, TI antibody responses have been considered exclusively short-lived and incapable of conferring long-lasting protection.

\section{2}

\section{T cell-dependent and -independent antigens}

Protein antigens such as tetanus, diphtheria and pertussis toxins are potent immunogens. They induce generation of antigen-specific $\mathrm{T}$ cells that help $\mathrm{B}$ cells by providing cognate and non-cognate interactions crucial for B cell responses. Such antigens are referred to as TD antigens. Vaccines comprised of this group of antigens generate highly protective and long-lasting antibody responses (Zinkernagel, 2000). Antigens that induce antibody responses without T cell-help are referred to as TI 
antigens (Fagarasan and Honjo, 2000; Vos et al., 2000). TI antigens are typically resistant to proteolysis and cannot be processed and presented to T helper cells via MHC class II, and thus are not capable of establishing cognate interaction with T cells, which can account for the restricted immunogenic nature of TI antigens (Lesinski and Westerink, 2001). TI type 1 (TI-1) antigens, the prototype of which is bacterial lipopolysaccharide (LPS), activate B cells primarily by stimulating mitogenic receptors e.g. Toll-like receptors (TLRs). Therefore, the antibodies generated by such stimuli are predominantly polyclonal (Vos et al., 2000). On the other hand, type 2 (TI-2) antigens such as bacterial capsular polysaccharides (PS) and other macromolecules with repetitive antigenic determinants, can induce antibody responses by primarily cross-linking the BCR of specific B cells (Vos et al., 2000).

\section{3}

\section{B cell subsets}

Mature B cells that generate antibody responses can be divided into four subsets; namely, follicular (FO), marginal zone (MZ), B1a and B1b subsets (Martin and Kearney, 2001; Montecino-Rodriguez and Dorshkind, 2006). Each appears to have a distinct function in the immune system. FO B cells (also known as B2 cells), comprise the majority of B cells in the body, re-circulate among the B-cell rich lymphoid follicles, participate in germinal center reactions, and mount TD antibody responses (McHeyzer-Williams, 2003). MZ B cells localized to the marginal sinus of the spleen, are strategically located to capture blood-borne TI particulate antigens and mount a very rapid response (Martin and Kearney, 2000; Martin and Kearney, 2001). The B1a subset is abundant in coelomic cavities but can also be found in the spleen (Martin and Kearney, 2000; Martin and Kearney, 2001). B1a cells though developmentally distinct from MZ B cells are also efficient in generating TI antibody responses (Berland and Wortis, 2002). B1a and MZ B cell subsets recognize evolutionarily conserved antigens such as phosphorylcholine moieties present on bacteria. When mice are challenged with phosphorylcholine-expressing bacteria such as Streptococcus pneumoniae, these two B cell subsets unite in the development of a rapid response (Martin et al., 2001). Aspects contribute to this response include, the ability of these B cell subsets differentiate into plasmablasts rapidly. Primed accessory cells of the myeloid lineage such as dendritic cells and macrophages appear to facilitate this response (Balasz et al., 2002; Martin and Kearney, 2001). Nevertheless, B1a cells constitutively secrete antibodies mainly of the IgM isotype and are referred to as natural antibodies because they occur spontaneously in human cord 
blood, in naïve "antigen-free" mice, and in normal individuals in the absence of apparent antigenstimulation (Boes, 2000). These antibodies have been shown to play an important role in controlling a wide range of pathogens (Boes, 2000). Although the B1b subset was described years ago (Stall et al., 1992), a functional role for these cells in protective immune responses has not been found until recently (Alugupalli et al., 2004; Haas et al., 2005; Hsu et al., 2006).

\section{4}

\section{B1b cells}

B1b cells share a number of features with B1a cells including the expression of cell-surface markers and anatomical location, e.g. the peritoneal cavity (PerC) (Stall et al., 1992). Both subsets express high levels of membrane $\operatorname{IgM}$ and Mac1 (integrin $\alpha_{\text {Mac }}$ ), low levels of $\operatorname{IgD}$ and B220 and lack CD23 expression. The only phenotypic marker to date that distinguishes these two B1 subsets is the expression of CD5 on B1a but not on B1b cells. Additional differences in developmental pathways (Montecino-Rodriguez et al., 2006; Tung et al., 2006) and cytokine responses also exist between these two subsets. Unlike the consistent expression of CD5 on B1a cells found elsewhere, e.g. spleen, the expression of Mac1 is restricted to the B1a and B1b cells localized to the PerC. Thus, identification of the B1b subset in sites other than PerC is limited by the lack of any other B1b-specific phenotypic marker. Interestingly, a recent analysis of PerC cells from chimeric mice revealed that an $\operatorname{IgM}^{\text {high }}, \operatorname{IgD}^{\text {low/- }}, \mathrm{Mac1}^{+} \mathrm{B} 1$ cell population emerges over time in Rag $1^{-/-}$mice reconstituted with wildtype peripheral lymph node cells (Hsu et al., 2006). The majority of their PerC B1 cell population lacked CD5 expression, indicating that lymph node cells predominantly reconstitute the B1b but not the B1a compartment. Thus, the number of B1b cells and/or B1b cell precursors in mice could be far more abundant than those found in coelomic cavities. The small number of B cells transferred compared to the numbers of $\mathrm{B} 1 \mathrm{~b}$ cells recovered in the PerC of the $\mathrm{Rag} 1^{-/-}$chimeras likely reflects proliferation of these cells after transfer, as the B1 cell subsets are known to maintain their numbers in the PerC by their unusual self-renewing capability even after an arrest of bone marrow B lymphopoiesis (Carvalho et al., 2001; Kantor et al., 1995). Although the reasons are not clear, the mechanism for the preferential homing of B1a and B1b cell subsets to the PerC appears to be due to their selective attraction to CXCL13, a chemokine produced by cells in the omentum and by peritoneal 
macrophages (Ansel et al., 2002). Mice deficient in CCR7 and CXCR5, the receptor for CXCL13, also exhibit a PerC homing defect of B1 cells (Hopken et al., 2004; Muller et al., 2003). As a consequence of this migration impairment the immunity of the coelomic cavity is significantly compromised in these mice (Ansel et al., 2002). Parabiosis experiments revealed that B1 cell subsets do not actively circulate compared to B2 cells (Ansel et al., 2002).

Nevertheless, PerC B1 cells have the capability to leave the PerC upon appropriate stimulation. In a transgenic B1 cell mouse model it was shown that microbial products induce the migration of PerC B1 cells to mesenteric lymph nodes where they rapidly differentiate into antibodysecreting cells (Watanabe et al., 2000). Recently, it was demonstrated that Toll-like receptor (TLR)-mediated stimulation induces a rapid and transient down-regulation of integrins resulting in an efficient movement of cells of PerC B1 cells in a chemokine-dependent fashion (Ha et al., 2006). These data and the presence of B1b cells or their precursors in the lymph node suggest that they can move in a dynamic fashion and are poised to encounter pathogens not only in the PerC but elsewhere with high frequency and thus play an important role in protective immunity.

5

\section{Role of B1b cells in $\mathbf{T}$ cell-independent responses}

\section{1}

\section{Immunity to Borrelia hermsii}

While investigating the immune mechanism required for controlling the relapsing fever bacterium $B$. hermsii, we found for the first time a specific function for B1b cells in protective immunity. Rodents are natural reservoirs for relapsing fever bacteria, and murine infection recapitulates the critical pathophysiological aspects of the human disease ( Southern and Sanford, 1969; Cadavid et al., 1994; Garcia-Monco et al., 1997; Gebbia et al., 1999; Alugupalli et al., 2001a; Alugupalli et al., 2001b; Alugupalli et al., 2003b). The hallmark of this infection is recurrent episodes of high-level bacteremia $\left(\sim 10^{8}\right.$ bacteria/ml blood $)$, each caused by antigenically distinct populations of bacteria generated by DNA rearrangements of the genes encoding the variable major proteins (Barbour, 1990). Remarkably, each episode is resolved rapidly within one to three days (Barbour and Bundoc, 2001; Connolly and Benach, 2001; 
Alugupalli et al., 2003a). TI B cell responses are necessary and sufficient for controlling $B$. hermsii infection (Barbour and Bundoc, 2001; Alugupalli et al., 2003a). IgM is the most dominant isotype in TI responses (Martin and Kearney, 2001). We found that mice deficient only in the secretion of IgM, but not SHM or CSR, suffer persistently high bacteremia and become moribund, indicating that $\operatorname{IgM}$ is the essential antibody isotype required for controlling $B$. hermsii (Alugupalli et al., 2003a). Consistent with these results, it was shown that passive transfer of $\operatorname{IgM}$ from convalescent mice is sufficient to confer protection (Arimitsu and Akama, 1973; Yokota et al., 1997). Nevertheless, it was demonstrated that other IgG isotypes, e.g. IgG3 and IgG2b are also capable of conferring passive protection (Yokota et al., 1997). Since the control of a bacteremic episode occurs rapidly e.g. with in one to three days and IgM, the first isotype to be made during primary immune response to antigen/pathogen exposure (Boes, 2000), we anticipated that neither the generation of other immunoglobulin isotypes by CSR nor affinity maturation of variable regions of the immunoglobulin by SHM which typically takes more than a week, play a critical role in this process. Activation-induced cytidine deaminase (AID) is essential for both CSR and SHM that typically occurs during a TD germinal center reaction (Muramatsu et al., 2000). Indeed, the resolution of the bacteremia and the kinetics of the $B$. hermsii-specific IgM response are indistinguishable between wildtype and $\mathrm{AID}^{-/-}$mice, demonstrating that unmutated $\operatorname{IgM}$ is sufficient for controlling B. hermsii infection (Alugupalli et al., 2004).

To identify the B cell subsets that are capable of generating this protective IgM response we have infected IL- $7^{-/}$mice, which are deficient in FO B cells but not B1a, B1b and MZ B cell subsets (Carvalho et al., 2001) and found that they control bacteremia as efficiently as wildtype mice (Alugupalli et al., 2003a). Using bone marrow chimeric mice deficient in B1a cells, we have ruled out a requirement for $\mathrm{B} 1 \mathrm{a}$ cells in the protective response against $B$. hermsii (Alugupalli et al., 2004). Severe bacterial burden in splenectomized mice during the primary bacteremic episode suggested that MZ B cells play a role in controlling B. hermsii (Alugupalli et al., 2003a; Alugupalli et al., 2003b). Consistent with this, recently Bockenstedt and colleagues have demonstrated that MZ B cells mount anti-B. hermsii antibody responses (Belperron et al., 2005). Nonetheless, the rapid control of bacteremia during secondary episodes of a virulent strain or a moderate bacteremic episode by a partially attenuated strain of $B$. hermsii in 
splenectomized mice suggested that MZ B cells are not the only subset that contributes to protection. Having ruled out a role for the other three B cell subsets, we investigated whether B1b cells might play a role in controlling B. hermsii bacteremia. Mutations affecting the BCR signaling pathway result in a severe deficiency of B1 cell subsets, which are the major producers of IgM (Berland and Wortis, 2002). Due to the lack of a B1b-deficient mouse model, we examined a potential role for B1b cells in X-linked immunodeficient (xid) mice (Khan et al., 1995; Thomas et al., 1993). Bacteremic episodes in xid mice are more severe than those of wildtype mice, which suggest that B1b cells may play a role in controlling B. hermsii (Alugupalli et al., 2003a). Although xid mice were clearly impaired in bacterial clearance, by four weeks post-infection bacteremia was completely resolved, an apparent paradox if B1b cells are indeed critical for controlling bacteremia. One possible explanation is that the markedly reduced B1b subset of xid mice expands during this infection. In fact Kearney and colleagues (Martin et al., 2001) have previously shown that antigen-specific TI B cell clones expand in mice immunized with $S$. pneumoniae. To detect a potential expansion of B1b cells we analyzed the frequencies of PerC B cells in xid mice. Remarkably, the frequency of B1b cells as defined by the surface markers $\operatorname{IgM}^{\text {high }}, \operatorname{IgD}^{\text {low }}, \mathrm{Mac1}^{+}$and $\mathrm{CD}^{-}$in convalescent xid mice is significantly greater than in uninfected xid mice (Fig. 1A) and comparable to the frequency of B1 cells in wildtype mice (Alugupalli et al., 2003a). This expansion was selective for B1b cells but not for B1a or B2 cell subsets (Fig. 1B) and occurred regardless of whether the xid mice were infected with a highly virulent or a partially attenuated strain of B. hermsii. These findings indicate a role for B1b cells in the control of both high and moderate bacteremic episodes (Alugupalli et al., 2003a). Since $\operatorname{IgM}$ is essential for controlling this infection and B1b expansion was detected as early as by seven days post-infection (Fig. 1B), we predicted that xid mice would be capable of mounting an anti-B. hermsii IgM response, despite their inherent deficiency in pre-immune IgM levels. As predicted, with some delay, xid mice generated a specific IgM response coincident with the resolution of bacteremia (Alugupalli et al., 2007).

A significant increase in B1b cell numbers also occurs in TCR- $\beta \times \delta^{-/-}$mice, demonstrating that this expansion is a TI process (Fig. 1C). Remarkably, the convalescent TCR- $\beta \mathrm{x} \delta^{-/-}$were as resistant as that of the wildtype mice to re-infection suggesting that a memory-like response can be generated by B1b cells independent of a germinal center reaction (Alugupalli et al., 2004). 
Indeed, we eliminated a role for two very important TD germinal center events namely SHM and CSR in controlling B. hermsii infection (Alugupalli et al., 2004). Movement of PerC B1 cells is crucial for their protective immune responses (Ansel et al., 2002; Ha et al., 2006; Hopken et al., 2004; Muller et al., 2003). We, therefore, anticipated that B1b cells leave the PerC to differentiate into IgM secreting plasma cells that are critical for the B. hermsii immunity. Upon infection with $B$. hermsii, a rapid egress of B1b cells from the wildtype mouse PerC was also observed. The magnitude of the egression was directly proportional to the bacterial burden (Fig. 1D). Interestingly, soon after resolution of bacteremia B1b cell numbers in the PerC were rapidly restored to basal levels, suggesting an active turnover and that these cells are capable of participating in protective immunity in the blood stream (Fig. 1D).

To directly determine whether B1b cells are capable of providing long-lasting immunity, we transferred B1b cells from convalescent mice into Rag $1^{-/-}$mice that are otherwise completely incapable of eliminating $B$. hermsii (Alugupalli et al., 2003a). $\operatorname{Rag}^{-1-}$ mice reconstituted with B1b cells controlled $B$. hermsii bacteremia, demonstrating for the first time a crucial role for B1b cells in protective immunity (Alugupalli et al., 2004). The fact that naïve mice suffer recurrent bacteremic episodes indicates that naïve B1b cells are functionally less effective than convalescent B1b cells. As expected, transfer of the same number of naïve B1b cells to Rag $1^{-/-}$ mice conferred only partial protection (Alugupalli et al., 2004). Consistent with the requirement for IgM in the clearance of bacteremia, the transferred B1b cells in Rag $1^{-/-}$mice confer protection by mounting a specific IgM response against $B$. hermsii, and the generation of this IgM is coincident with the resolution of bacteremia. B1b cells do not mount an antibody response in the absence of specific stimulation, indicating that they maintain a quiescent state like conventional memory B cells (Alugupalli et al., 2004). This property of B1b cells is not unique to the $B$. hermsii infection, and recently has been extended to another important human pathogen, S. pneumoniae.

\section{2}

\section{Immunity to Streptococcus pneumoniae}

A number of clinically important pathogens including S. pneumoniae, Haemophilus influenzae 
and Neisseria meningitidis express PS capsules (Lesinski and Westerink, 2001). Some pathogens associated with biological threats such as Bacillus anthracis, the etiological agent of anthrax, express capsules made of poly- $\gamma$-D-glutamic acid (Wang and Lucas, 2004). Due to the restricted immunogenicity for TD responses, the masking of potentially immunogenic TD protein antigens, and the provision of serum resistance, capsules enable the persistence of these pathogens in the host and eventually cause serious diseases ranging from bacteremia to meningitis (Kelly et al., 2004; Scorpio et al., 2007). A critical factor in preventing these infections from becoming systemic is the ability of B cells to rapidly generate protective antibodies against capsules. As mentioned earlier, bacterial capsules are TI-2 antigens and antibodies to capsules are highly protective. In fact, the introduction of conjugate vaccine against the capsular PS (Hib) had a major impact in reducing the incidence of $H$. influenzae type b disease worldwide (Kelly et al., 2004).

Using a well-established murine model of $S$. pneumoniae infection in mice sufficient or deficient in CD19, Haas and colleagues found that CD19, though an important molecule for B cell development is, surprisingly, not necessary for generating protective $\operatorname{IgM}$ or IgG3 responses against the capsular PS of S. pneumoniae (Haas et al., 2005). CD19 ${ }^{-/-}$mice have a severe deficiency in B1a cells and MZ B cells but not B1b cells suggesting that this subset is responsible for the observed anti-PS specific antibody response. Conversely, CD19 transgenic (CD19Tg) mice that are severely deficient in B1b cells but not B1a or MZ B cells were incapable of mounting an antibody response to capsular PS (Haas et al., 2005). Immunization of CD19 ${ }^{-1-}$ but not CD19Tg mice with capsular PS protects mice from a lethal $S$. pneumoniae challenge. These correlations suggest that B1b cells might be involved in generating long-lasting anti-PS responses. To identify the $\mathrm{B}$ cell subsets responsible for the anti-PS antibodies, Haas and colleagues transferred wildtype B1b, B1a or MZ B cells into Rag $1^{-1-}$ mice. None of the reconstituted mice spontaneously generated anti-PS antibodies over a period of four weeks. However, upon PS immunization only B1b-reconstituted mice mounted an exuberant anti-PS IgM and IgG3 response (Haas et al., 2005). Unreconstituted mice died as early as two days postinfection when challenged with as few as 100 colony-forming units of S. pnuemoniae. In striking contrast greater than $75 \%$ of Rag $1^{-/}$mice reconstituted with B1b cells survived this lethal dose (Haas et al., 2005). These data demonstrate yet another example of B1b cell-mediated immunity to a clinically important bacterial pathogen. In the pneumococcal infection mouse model B1a cell 
subsets were also shown to play an important complementary role in protective immunity by virtue of their natural antibody repertoire. Unlike constitutively secreted natural antibodies, antibodies generated by B1b cells are inducible only by specific antigen stimulation (Haas et al., 2005), as in the case of B. hermsii-specific B1b cell response (Alugupalli et al., 2004). To date, two independent studies, using clinically distinct murine infection systems, reveal a long-lasting and antigen-specific B1b cell response (Alugupalli et al., 2004; Haas et al., 2005). In both cases the function of B1b cells was revealed unpresumptuously. Therefore, it is tempting to consider an important role for B1b cells in protection against other infections.

\section{3}

\section{Response to NP-Ficoll, a model TI-2 antigen}

Due to the division of labor within TI B cell subset responses during an infection and the host- or tissue-tropism of bacterial pathogens, it is not easy to dissect the role of B1b cells in other infection systems. Moreover, the lack of a B1b cell-specific marker currently poses a challenge in tracking B1b cell responses in compartments such as the spleen, lymph nodes and bone marrow. Nevertheless, while exploring the identity of B cell populations involved in the response to 4-hydroxy-3-nitrophenyl acetyl (NP), a frequently used hapten for studying antigen-specific antibody responses in mice, MacLennan and colleagues revealed an involvement for B1b cells in anti-NP responses (Hsu et al., 2006). NP-conjugated polysaccharide Ficoll is a widely used model antigen for studying TI-2 responses. It is known that extrafollicular antibody responses induced by immunization of NP-Ficoll persist for long periods of time (de Vinuesa et al., 2000). Adoptive transfer experiments were performed using Rag $1^{-/-}$mice reconstituted with wildtype mouse PerC cells which were depleted of either B2 or B1a cells. These mice generated normal levels of NP-specific IgM and IgG3 antibodies (Hsu et al., 2006). In contrast, Rag1/- mice reconstituted with $\mathrm{B} 1 \mathrm{a}$ and $\mathrm{B} 1 \mathrm{~b}$ cell-depleted PerC cells failed to generate NP-specific antibody responses indicating $\mathrm{B} 1 \mathrm{~b}$ cells are involved in this response (Hsu et al., 2006). In support of the specific induction of B1b cell-derived IgM seen in B. hermsii and S. pneumoniae infection models (Alugupalli et al., 2004; Haas et al., 2005), NP-specific B1b cells did not generate an anti-hapten response spontaneously (Hsu et al., 2006). The magnitude of the anti-NP response increased dramatically following NP-Ficoll immunization (Hsu et al., 2006), revealing once again a requirement for specific-antigen stimulation in the B1b cell response (Alugupalli et al., 
2004; Haas et al., 2005; Hsu et al., 2006). Surprisingly, Rag $1^{-/-}$mice reconstituted with lymph node B cells also generated NP-specific IgM and IgG3 responses as efficiently as the PerC cellreconstituted Rag ${ }^{-1-}$ mice (Hsu et al., 2006). Analysis of PerC cells isolated from lymph node cell-reconstituted Rag1 ${ }^{-{ }_{-}}$mice revealed a robust generation of $\mathrm{B} 1 \mathrm{~b}$ cells but not B1a cells. Approximately $2 \%$ of lymph node $\mathrm{B}_{2} 20^{+}$cells are $\mathrm{IgM}^{\text {high }}$ and $\mathrm{IgD}^{\text {low }}$ that are characteristics of $\mathrm{B} 1 \mathrm{~b}$ cells. These results indicate that B1b cells and/or B1b cell precursors are present in lymphoid compartments and are poised to contribute to TI-2 antigen-specific responses. Recently, it was demonstrated that IgM memory B cells are generated upon NP-Ficoll immunization and such cells can be detected in spleen (Obukhanych and Nussenzweig, 2006). The phenotype of these B cells is distinct from that of MZ B and FO B cells. It is possible that these cells might represent splenic B1b cells (Obukhanych and Nussenzweig, 2006).

\section{6}

\section{Activation of antigen-specific $\mathbf{T}$ cell-independent $\mathrm{B}$ cell responses}

Antigens driving B1b cell responses appear to be heterogenous. For example, one B. hermsii antigen targeted by B1b cells is a protein implicated in virulence of this pathogen (M. J. Colombo and K. R. Alugupalli, unpublished data). In the case of S. pneumoniae it is a carbohydrate (Haas et al., 2005), whose expression is implicated in a variety of immune evasion strategies. Thus, the recognition of biochemically different bacterial products and even synthetic haptens such as NP (Hsu et al., 2006) by B1b cells clearly indicates that the B1b repertoire is capable of responding to a wide spectrum of antigens. Unbiased analysis of the CDR3 regions of $\mathrm{VH}$ genes revealed that unlike B1a cells, B1b cells have high junctional diversity that is comparable to B2 cells (Kantor et al., 1997; Tornberg and Holmberg, 1995). Furthermore, immunization with NP-Ficoll can result in low levels of SHM in the VH regions even without T cell help (Toellner et al., 2002). This process presumably occurs by BCR cross-linking induced AID expression without the requirement for CD40-CD40L (Faili et al., 2002; Weller et al., 2001). This could also explain the existence of other antibody isotypes e.g. IgG3 by CSR during TI responses (Martin and Kearney, 2001). However, unlike conventional B2 cells, the affinity and overall Ig repertoire of B1b cell-derived antibodies may be limited due to the lack of an involvement with TD germinal center reactions. 


\section{1}

\section{Role of Btk in $T$ cell-independent $B$ cell responses}

Although antigen-specific B1b cells respond to various TI antigens e.g. pneumococcal PS, hapten NP and B. hermsii surface protein (Haas et al., 2005; Hsu et al., 2006) (M. J. Colombo and K. R. Alugupalli, unpublished data), the mechanism of activation of this response can vary. Xid mice, which carry a point mutation in Bruton's tyrosine kinase (Btk), a cytoplasmic kinase belonging to the Tec family of kinases is crucial for BCR-mediated activation. B cells of these mice cannot respond to anti-BCR cross-linking and are therefore impaired primarily in response to TI-2 antigens such as NP-Ficoll (Amsbaugh et al., 1972; Khan et al., 1995; Scher et al., 1975; Thomas et al., 1993). In fact, these mice cannot generate protective antibody responses to capsules of S. pneumoniae or B. anthracis (Briles et al., 1981; Wang and Lucas, 2004). Mice that have a targeted deletion in the Btk gene recapitulate the xid mouse phenotype (Khan et al., 1995). Surprisingly, the phenotypes seen in these mice are not identical to X-linked agammaglobulinemia (XLA) patients, the human equivalent of xid. Mice deficient in Tec, a kinase belonging to the same family as Btk, have no major phenotypic alterations of the immune system (Ellmeier et al., 2000). Interestingly, mice deficient in both Btk and Tec exhibit a phenotype that is similar to human XLA (Ellmeier et al., 2000). Although the exact reasons for these differences is not clear, it was demonstrated that retroviral-mediated transfer of the human Btk gene corrects a number of functions including TI-2 responses in Btk and Tec double knockout mice, indicating a functionally conserved and crucial role of Btk in both mice and humans (Yu et al., 2004). Xid mice respond to LPS, a model TI-1 antigen (Hiernaux et al., 1983; Mosier et al., 1977). The moderate impairment of xid mouse B cells to LPS stimulation (Khan et

al., 1995) is likely due to a potential role for Btk in TLR-mediated signaling rather than its role in BCR-mediated signal (Jefferies et al., 2003; Jefferies and O'Neill, 2004), as the IgM response induced by LPS is polyclonal and non-specific (Andersson et al., 1972; Mosier et al., 1976). In support of this, it was shown that mice deficient in MyD88 involved in TLR- but not BCRmediated signaling exhibit impaired LPS-induced B cell activation (Kawai et al., 1999).In fact, these mutant mice generate normal anti-NP-Ficoll antibody responses (Schnare et al., 2001). These data together reveals the critical role for Btk in TI-2 responses. 
Although xid mice are deficient in B1 cells, as previously mentioned (see Sect. 5.1), the impairment of a specific antibody response to TI-2 antigens is not entirely due to a deficiency of these B cell subsets. Increasing the B cell numbers in xid mice by blocking apoptosis of B cells with the transgenic expression of $\mathrm{Bcl} 2$, does not restore $\mathrm{B}$ cell functions including TI-2 responses in xid mice (Woodland et al., 1996). Transgenic expression of IL-9 or injection of this cytokine induces selective expansion of B1b cells in wildtype mice (Vink et al., 1999). Such a transgene can even correct the B1b cell deficit of xid mice but does not restore the specific antibody response to pneumococcal capsular PS or NP-Ficoll (Knoops et al., 2004). In contrast, a Btk transgene restores NP-Ficoll and antiviral TI-2 responses of xid mice in a dose-dependent fashion (Pinschewer et al., 1999; Satterthwaite et al., 1997). Furthermore, the defective anti-PS response of xid mice is not attributed to lack of a specific VH gene family involved in TI-2 responses (Feng and Stein, 1991; Selinka and Bosing-Schneider, 1988). These data suggest that the impaired TI response in xid mice is due to a compromised BCR-mediated signal rather than a deficiency in $\mathrm{B} 1 \mathrm{~b}$ cells or the potential deficiency in the BCR repertoire itself.

\section{2}

\section{Role of co-stimulatory signals in $\mathrm{T}$ cell-independent $\mathrm{B}$ cell responses}

\subsection{1}

\section{CD40 and its ligand CD40L}

Despite a BCR-mediated signaling defect, $x i d$ or $\mathrm{Btk}^{-/-}$mice generate near normal responses to TD antigens (Khan et al., 1995). This response is likely mediated by CD40-Cd40L costimulation provided by $\mathrm{T}$ cells, since mice deficient in both Btk and CD40 are severely compromised for TD antibody responses (Khan et al., 1997). In fact, in vitro co-stimulation of xid $\mathrm{B}$ cells with CD40 compensates the need for Btk in BCR-mediated signal as detected by cell cycle progression and nuclear translocation of NF- $\mathrm{KB}$, a transcription factor involved in a variety of B cell responses (Mizuno and Rothstein, 2003; Mizuno and Rothstein, 2005). Consistent with this, injection of anti-CD40 antibodies as a surrogate for CD40L restores immune responses to NP-Ficoll in xid mice (Dullforce et al., 1998; Vinuesa et al., 2001). In striking contrast to that of typical TI-2 responses induced by capsular PS or NP-Ficoll, the antibody response to $B$. hermsii 
is clearly different. For example, unlike pure TI-2 antigens, an active infection is expected to engage several immune activation pathways. Although xid mice suffer more severe bacteremia than wildtype mice, they control all episodes of $B$. hermsii bacteremia and the resolution of the infection coincides with an expansion of B1b cells in these mice (see Sect. 5.1) (Alugupalli et al., 2003a). Xid mouse B cells are defective in homeostatic proliferation (Cabatingan et al., 2002; Woodland and Schmidt, 2005), hence this B1b cell expansion is likely to be antigen-driven. In support of this, xid or Btk ${ }^{-/-}$mice generate an antigen-specific IgM response capable of controlling infection (Alugupalli et al., 2007). The magnitude of the specific IgM response in wildtype mice is comparable to that of TCR- $\beta \mathrm{x} \delta^{-/-}$mice, implying an unlikely for role CD40CD40L-mediated co-stimulation, provided by T cells in this infection (Alugupalli et al., 2007) (Fig. 2A). The observation that CD40L $\mathrm{L}^{-/-}$mice generate a robust TI IgM response to the related bacterium B. burgdorferi supports this notion (Fikrig et al., 1996). Although the physiological relevance of CD40-CD40L interaction in TI responses is not clear, the above data indicate that a role exists for alternate pathways of activation during TI responses.

\subsection{2}

\section{Complement component $\mathrm{C} 3$ and its receptor $\mathrm{CR} 1 / 2$}

The high expression of CR1/2, the C3 receptor on MZ B cells (Zandvoort and Timens, 2002), is necessary for specific targeting of C3 conjugated TI-2 antigens such as Pneumococcal capsular PS to MZ B cell (Breukels et al., 2005; Guinamard et al., 2000). Mice deficient in C3 have reduced responses to TI-2 antigens (Guinamard et al., 2000). Some viral pathogens also behave like TI antigens and induce TI-2 like responses in vivo (Fehr et al., 1998; Ochsenbein et al., 1999; Szomolanyi-Tsuda et al., 2001; Szomolanyi-Tsuda and Welsh, 1998). Studies of vesicular stomatitis virus have demonstrated a correlation between antigen repetitiveness (TI-2 like arrangement) and the degree to which B-cell activation is independent of T cells. The rigidly structured Poliovirus efficiently induces neutralizing IgM antibodies independent of T cell-help (Fehr et al., 1998). For example, Poliovirus and Vaccinia virus expressing vesicular stomatitis virus glycoproteins do not induce antibody responses in xid mice (Pinschewer et al., 1999; Szomolanyi-Tsuda et al., 2001). However, as mentioned earlier, a Btk transgene compliments these responses in xid mice suggesting that BCR-signaling is the limiting component 
(Pinschewer et al., 1999). However, impaired TI responses to these viral pathogens, in $\mathrm{C}^{-{ }^{--}}$or $\mathrm{CR}^{-/-}$mice, implied that simultaneous engagement of C3-coupled antigen to $\mathrm{CR} 1 / 2$ and BCR promotes B cell stimulation (Ochsenbein et al., 1999; Szomolanyi-Tsuda et al., 2006). In fact, priming of human B cells with C3 engagement to CR1/2 enhances anti-IgM-mediated B cell activation even to very low levels of BCR crosslinking (Carter and Fearon, 1989; Carter et al., 1988). This co-stimulatory pathway seems to be more appropriate for the activation of MZ B cells than B1b cells. For instance, the B1b but not MZ B cells are crucial for the clearance of $B$. hermsii and $\mathrm{C}^{-/-}$mice control this infection efficiently (Connolly and Benach, 2001; Connolly et al., 2004). The kinetics of the anti-B. hermsii $\operatorname{IgM}$ response in $\mathrm{C} 3^{-/-}$mice is comparable to that of wildtype mice (Fig. 2A). This result is in agreement with the C3-independent IgM-mediated killing of relapsing fever bacteria (Connolly and Benach, 2001; Connolly et al., 2004).

Xid B cells respond to TI-2 antigens when co-stimulated by IL-1 (Couderc et al., 1987). However, we found that IL-1R $\mathrm{R}^{-/-}$mice generate robust $\mathrm{IgM}$ response to $B$. hermsii (Fig. 2A) (Alugupalli et al., 2007). Our results on the pathogen-specific IgM response in xid or Btk ${ }^{-/-}$ mouse infections suggested that even in the absence of normal BCR-mediated signaling, $B$. hermsii is capable of rapidly activating antigen-specific B cells, presumably by stimulating other signaling pathways such as the TLR-mediated pathway. In fact, when xid B cells are costimulated with TLR ligands, they respond to BCR cross-linking (Couderc et al., 1987).

\subsection{3}

\section{Toll-like receptors}

TLRs play important roles in activation of the immune system (Takeda and Akira, 2005). Importantly, TLR9 has been shown to activate auto-reactive B cells (Leadbetter et al., 2002) and memory B cells (Bernasconi et al., 2002), indicating a possible role for TLR9 in the development of rapid and long-lasting TI-2 antibody responses. $B$. hermsii being a prokaryote is expected to contain a high frequency of CpG DNA, the ligand for TLR9. Despite these expectations, TLR9 ${ }^{-/-}$ mice generate rapid anti-B. hermsii IgM responses. $B$. hermsii possess other potential TLR ligands such as lipoproteins, the ligands for TLR2 (Shang et al., 1998) that could redundantly activate distinct members of the TLR family, thereby restoring responses in xid mice. Indeed, 
mice deficient in MyD88, a common cytoplasmic adaptor for all TLRs except TLR3, exhibited a significantly delayed anti-B. hermsii IgM response (Fig. 2B). Analysis of individual TLR knockout mice revealed important roles for TLR1 and TLR2 in anti-B. hermsii IgM responses (Alugupalli et al., 2007). CD14 is known to augment TLR2-mediated responses and as expected, $\mathrm{CD}_{14}{ }^{-/}$mice have impaired antibody response to B. hermsii (Alugupalli et al., 2007). CD14 is not only involved in TLR2 signaling but also in TLR4-mediated signaling. Although B. hermsii is not a Gram-negative bacterium and hence does not contain LPS, other evolutionarily distant microbial components such as glycolipids of Treponema (Schroder et al., 2000), pneumolysin of S. pneumoniae (Malley et al., 2003) and fusion protein of respiratory syncitial virus (Kurt-Jones et al., 2000) are recognized by TLR4. This may explain the delayed and reduced $B$. hermsiispecific IgM response in TLR2 ${ }^{-/-}$mice. The magnitude of the specific IgM response in TLR4 ${ }^{-/-}$ mice was also somewhat lower than wildtype mice (Alugupalli et al., 2007). As expected, this potential TLR4-mediated response did not resemble an LPS-induced response, since mice deficient in MD2, a protein crucial for the LPS response (Nagai et al., 2002), generated normal antibody responses (Alugupalli et al., 2007). These results indicate that $B$. hermsii may also signal through TLR4 in addition to TLR1 and TLR2, by a mechanism distinct from that of LPSinduced stimulation. Mice deficient in TLR3, which is involved in recognizing double-stranded RNA, a signature for viral rather than bacterial infection, generated IgM responses comparable to wildtype mice (Alugupalli et al., 2007).

Due to the redundancy in TLRs, we tested whether MyD88 provides synergistic or partially redundant functions in triggering an antibody response to $B$. hermsii in xid mice. Indeed, mice deficient in both Btk and MyD88 are severely compromised in IgM production and bacterial clearance but not TD antibody responses that utilize CD40-CD40L (Alugupalli et al., 2007). Despite a normal response both in terms of kinetics and magnitude of specific $\operatorname{IgM}$ or IgG to the model TD antigen NP-conjugated chicken gammaglobulin, Btk x MyD88 ${ }^{-/-}$mice are unable clear B. hermsii even transiently, highlighting the critical role for TI responses in protective immunity (Alugupalli et al., 2007) (Fig. 2B). Although B1b cells are capable of efficiently recognizing chemically distinct antigens, these data suggest the involvement of a costimulatory mechanism in B1b cell activation during TI responses. Understanding the source of 
TLR signaling and how they regulate B1b cell function may help develop strategies to restore efficient responses in individuals with impaired TI responses.

\section{7}

\section{Impaired T cell-independent $B$ cell responses}

Children and the elderly respond poorly to TI antigens, and as a consequence suffer severe and recurrent infections by both encapsulated and non-encapsulated bacteria (Kelly et al., 2004;

Kelly et al., 2005; Lesinski and Westerink, 2001). A number of possibilities could account for this impairment, some of which are reminiscent of the defects seen in xid mice, suggesting that the xid mouse is an appropriate model for studying impaired TI responses in children. Similar to the BCR-mediated activation defect of xid B cells (Couderc et al., 1987), it has been shown that the B cells of neonatal, very young and aged wildtype mice exhibit an activation defect to PS antigens and multivalent membrane Ig crosslinking, a mimic of TI-2 antigen-induced stimuli (Chelvarajan et al., 1998; Chelvarajan et al., 1999; Snapper et al., 1997). This impairment of the surface IgM cross-linking and NP-Ficoll responses in neonatal B cells can be corrected by a number of above mentioned (see Sect. 6) co-stimulatory signals for xid B cells (Couderc et al., 1987; Vinuesa et al., 2001) such as CD40-L, TLR ligands, IL-1 and IL-6 (Chelvarajan et al., 1998; Chelvarajan et al., 1999; Snapper et al., 1997). A defect in accessory cell-mediated costimulation for neonatal and aged mouse B cell activation has also been proposed for the poor responses of children and the elderly. These accessory cells are mainly of the myeloid lineage, such as monocytes and macrophages but not T cells (Bondada et al., 2000; Chelvarajan et al., 2004; Chelvarajan et al., 2005; Chelvarajan et al., 2006; Landers et al., 2005; Yan et al., 2004a; Yan et al., 2004b). In fact, compared to adult human monocytes, neonatal monocytes express significantly lower levels of MyD88 protein, which is required for IL-1 and almost all TLRmediated signalings (Yan et al., 2004b). In agreement with these signaling defects, we have recently demonstrated that mice deficient in both MyD88 and Btk are severely compromised for TI antibody responses (see Sect. 6.2.3).

The lack of appropriate B cell subsets and/or IgM memory B cells could also explain the impaired TI responses in the young (Kruetzmann et al., 2003; Zandvoort et al., 2001). For 
example, the lack of MZ B cell development and the low expression of CR1/2 on MZ B cells in the spleens of children under 2 years of age has been suggested as a reason for their impaired responses to PS (Zandvoort and Timens, 2002). Nevertheless, upon immunization with NPFicoll, pyk- $2^{-/-}$mice, deficient in MZ B cells but not B1 cells, generate IgM and IgG3 antibody responses more than two orders of magnitude higher than pre-immune levels (Guinamard et al., 2000). This implies that other B cells, likely B1b cells, play an important role in this TI-2 response. In agreement with this possibility two independent studies reviewed here (see Sect. 5.2 $\&$ 5.3) provided direct evidence using $\mathrm{Rag} 1^{-/-}$chimeras that B1b cells generate the majority of the anti-TI-2 IgM and IgG3 responses to NP-Ficoll and PS (Haas et al., 2005; Hsu et al., 2006). It is interesting that the splenic localization of PS conjugates can also be independent of the presence of C3 (Breukels et al., 2005), which could explain the significant NP-Ficoll response in pyk- $2^{-/-}$mice (Guinamard et al., 2000). In agreement with this, mice deficient in CD19, the signal-transducing moiety of the $\mathrm{C} 3$ receptor $\mathrm{CR} 1 / 2$, generate $\mathrm{B} 1 \mathrm{~b}$ cells normally and mount efficient protective antibody responses to capsular PS (Haas et al., 2005). In fact, $\mathrm{C} 3^{-/-}$mice also generate normal IgM responses to B. hermsii (Fig. 2A) (Connolly and Benach, 2001; Connolly et al., 2004). While it is not clear that all distinctions between $B$ cell subsets defined in the mouse hold true for humans, these data also suggest that children lack sufficient protection from functional IgM-secreting (memory) B1b cells. Such a lack in the rapid as well as long-lasting responses to $\mathrm{TI}$ antigens by B1b cells may explain recurrent infections by encapsulated bacterial pathogens in children.

8

\section{Memory B1b cells}

The functional definition of immunological memory is the ability of the immune system to respond more rapidly and effectively to pathogens that have been encountered previously and reflect the pre-existence of clonally expanded populations of antigen-specific lymphocytes (Janeway et al., 2004). The long-term immunity provided by B1b cells functionally resembles that of canonical B cell memory, however it is generated and maintained in the complete absence of T cells (Alugupalli et al., 2004).

The B1b cell responses to three distinct TI antigens reviewed here (Sect. 5.1, 5.2.and 5.3) 
have revealed strikingly common characteristics to memory B cell responses. Such characteristics include i) the generation of $\mathrm{B} 1 \mathrm{~b}$ cell responses that do not require continuous $\mathrm{B}$ lymphopoeisis (Alugupalli et al., 2003a; Carvalho et al., 2001); ii) B1b cells maintain their numbers by self-renewal (Kantor et al., 1995); iii) B1b cells maintain a quiescent state in terms of their differentiation into plasma cells, and their activation requires specific-antigenic stimulation (Alugupalli et al., 2004; Haas et al., 2005; Hsu et al., 2006); and iv) B1b cells generate long-lasting antibody responses (Alugupalli et al., 2004; Haas et al., 2005; Hsu et al., 2006). In the $B$. hermsii-infection system, expanded B1b cells persist for a remarkably long-time in convalescent mice (Fig. 1B) and upon challenge, expanded B1b cells rapidly differentiate into antibody secreting cells (Alugupalli et al., 2004). While naïve B1b cells also generate specific IgM, the magnitude of the response is significantly lower compared to that of expanded B1b cells. The kinetics of the IgM response is also considerably delayed (Alugupalli, unpublished data). These properties indicate that a subset of B1b cells behave like memory B cells. Reasons that account for the evolution of the enhanced protection or antibody responses by such a subset may include an expansion of antigen-specific B1b cells. In addition, antigenic stimulation may have conferred upon the immune or convalescent mouse B1b cells a distinct property that naïve B1b cells do not possess, similar to those that distinguish TD memory B cells from naïve B cells as illustrated in Fig. 3.

The robust binding of B1b cell-derived IgM to B. hermsii without SHM (Alugupalli et al., 2004) suggests an increased quantity of antigen-specific B1b cells in convalescent mice rather than an affinity maturation of $\mathrm{VH}$ regions of specific $\mathrm{B} 1 \mathrm{~b}$ clones. Interestingly, the $\mathrm{VH}$ sequences of the majority of the Ig repertoire of NP-Ficoll immunized mice have no SHM and are of the IgM isotype (Maizels and Bothwell, 1985; Maizels et al., 1988). This unmutated IgM response is not unique to the carrier, Ficoll. In fact, mice deficient in BCL6, which cannot develop germinal center reaction, are capable of mounting hapten-specific antibody responses when immunized with NP-conjugated to chicken gammaglobulins as a carrier, a frequently used model TD antigen. The VH regions of the NP-specific IgM memory B cells in BCL6 ${ }^{-/-}$mice are also unmutated. These results indicate that generation of unmutated $\operatorname{IgM}$ memory occurs without germinal center formation and is specific to the antigen driving such response (Toyama et al., 2002). In fact, such an unmutated IgM response is sufficient for conferring immunity even to a rapidly replicating bacterial pathogen, since TI control of $B$. hermsii occurs in AID $^{-/-}$mice. 
Furthermore, we have also shown that convalescent $\mathrm{AID}^{-/-}$mice are also resistant to re-infection demonstrating that the unmutated IgM memory of B1b cells is functional (Alugupalli et al., 2004).

9

\section{Concluding remarks}

To date three distinct model systems have revealed that B1b cell subsets mount the majority of the antigen-specific TI response (Alugupalli et al., 2003a; Alugupalli et al., 2004; Haas et al., 2005; Hsu et al., 2006). This B1b cell subset is also capable of generating a unique response that is functionally but not developmentally similar to the classical memory B cell response. The generation of rapid and long-lasting IgM induction from the B1b cell subset, may not be an unnecessary complexity in the seemingly linear conventional TD B cell memory development as opinioned recently (Tarlinton, 2006). The existence of B1b cell memory does not appear to be a redundant arm of the memory B cell compartment, as B1b cell memory has already been shown to play an indispensable role in two clinically important bacterial infections (Alugupalli et al., 2004; Haas et al., 2005). In fact, TD responses do not contribute to the protective immunity in these systems. The dichotomy in the development of B cell memory, such as the generation of TI memory B1b cells and canonical TD memory B cells seem to imply the humoral immune system's inherent strategy to cover two major categories of immunogens, the TI and TD antigens, respectively. The division of labor by these two distinct arms of B cell memory could ensure achieving "sterilizing" immunity to a wider range of pathogens in an overlapping and timely fashion. The rapid and antigen-specific IgM response enhances the germinal center reactions by forming antigen-IgM complexes and facilitates an accelerated development of high affinity antibody response to TD antigens, suggesting a role for B1b-derived IgM in the development of canonical B cell memory (Corley et al., 2005). In addition, B1b cell-derived TI responses may also be beneficial in decreasing the incidence of morbidity associated with opportunistic pathogens in individuals with decreased $\mathrm{T}$ cell counts and T-cell dysfunction (Chinen and Shearer, 2002). For instance, a selective reduction in $\mathrm{CD} 27^{+}$conventional memory B cells in drug-naïve and in highly active anti-retroviral therapy-treated HIV-1-infected individuals compromises their TD responses and increases susceptibility to a number of opportunistic infections (Chong et al., 2004). Elucidation of the developmental pathways 
involved in B1b cell generation, activation, expansion and long-term maintenance of antigenspecific B1b cells may provide new approaches to the induction of long-lasting protective antibody responses in individuals impaired in TI and/or TD responses. 


\section{Acknowledgements}

I thank the support from NIH/NIAID RO1 AI065750. I dedicate this review to the memory of my brother, Dr. Srinivas Alugupalli. 


\section{References}

Alugupalli, K. R., Akira, S., Lien, E., and Leong, J. M. (2007). MyD88- and Bruton's tyrosine kinase-mediated signals are assential for T cell-independent pathogen-specific IgM responses. J Immunol 178, 3740-3749.

Alugupalli, K. R., Gerstein, R. M., Chen, J., Szomolanyi-Tsuda, E., Woodland, R. T., and Leong, J. M. (2003a). The resolution of relapsing fever Borreliosis requires IgM and is concurrent with expansion of B1b lymphocytes. J Immunol 170, 3819-3827.

Alugupalli, K. R., Leong, J. M., Woodland, R. T., Muramatsu, M., Honjo, T., and Gerstein, R. M. (2004). B1b Lymphocytes confer T cell-independent long-lasting immunity. Immunity 21, 379-390.

Alugupalli, K. R., Michelson, A. D., Barnard, M. R., and Leong, J. M. (2001a). Serial determinations of platelet counts in mice by flow cytometry. Thromb Haemost 86,668 671.

Alugupalli, K. R., Michelson, A. D., Barnard, M. R., Robbins, D., Coburn, J., Baker, E. K., Ginsberg, M. H., Schwan, T. G., and Leong, J. M. (2001b). Platelet activation by a relapsing fever spirochete results in enhanced bacterium-platelet interaction via integrin $\alpha \operatorname{IIb} \beta 3$ activation. Mol Microbiol 39, 330-340.

Alugupalli, K. R., Michelson, A. D., Joris, I., Schwan, T. G., Hodivala-Dilke, K., Hynes, R. O., and Leong, J. M. (2003b). Spirochete-platelet attachment and thrombocytopenia in murine relapsing fever borreliosis. Blood 102, 2843-2850.

Amsbaugh, D. F., Hansen, C. T., Prescott, B., Stashak, P. W., Barthold, D. R., and Baker, P. J. (1972). Genetic control of the antibody response to type 3 pneumococcal polysaccharide in mice. I. Evidence that an X-linked gene plays a decisive role in determining responsiveness. J Exp Med 136, 931-949.

Andersson, J., Sjoberg, O., and Moller, G. (1972). Induction of immunoglobulin and antibody synthesis in vitro by lipopolysaccharides. Eur J Immunol 2, 349-353.

Ansel, K. M., Harris, R. B., and Cyster, J. G. (2002). CXCL13 is required for B1 cell homing, natural antibody production, and body cavity immunity. Immunity 16, 67-76.

Arimitsu, Y., and Akama, K. (1973). Characterization of protective antibodies produced in mice infected with Borrelia duttonii. Jpn J Med Sci Biol 26, 229-237. 
Balasz, M., Martin, F., Zhou, T., and Kearney, J. F. (2002). Blood dendritic cells interact with splenic marginal zone B cells to initiate T-independent immune responses. Immunity 17 , 341-352.

Barbour, A. G. (1990). Antigenic variation of a relapsing fever Borrelia species. Annu Rev Microbiol 44, 155-171.

Barbour, A. G., and Bundoc, V. (2001). In vitro and in vivo neutralization of the relapsing fever agent Borrelia hermsii with serotype-specific immunoglobulin M antibodies. Infect Immun 69, 1009-1015.

Belperron, A. A., Dailey, C. M., and Bockenstedt, L. K. (2005). Infection-induced marginal zone B cell production of Borrelia hermsii-specific antibody is impaired in the absence of CD1d. J Immunol 174, 5681-5686.

Berland, R., and Wortis, H. H. (2002). Origins and functions of B-1 cells with notes on the role of CD5. Annu Rev Immunol 20, 253-300.

Bernasconi, N. L., Traggiai, E., and Lanzavecchia, A. (2002). Maintenance of serological memory by polyclonal activation of human memory B cells. Science 298, 2199-2202.

Boes, M. (2000). Role of natural and immune IgM antibodies in immune responses. Mol Immunol 37, 1141-1149.

Bondada, S., Wu, H., Robertson, D. A., and Chelvarajan, R. L. (2000). Accessory cell defect in unresponsiveness of neonates and aged to polysaccharide vaccines. Vaccine 19, 557-565.

Breukels, M. A., Zandvoort, A., Rijkers, G. T., Lodewijk, M. E., Klok, P. A., Harms, G., and Timens, W. (2005). Complement dependency of splenic localization of pneumococcal polysaccharide and conjugate vaccines. Scand J Immunol 61, 322-328.

Briles, D. E., Nahm, M., Schroer, K., Davie, J., Baker, P., Kearney, J., and Barletta, R. (1981). Anti-phosphocholine antibodies found in normal mouse serum are protective against intravenous infection with type 3 Streptococcus pneumoniae. J Exp Med 153, 694-705.

Cabatingan, M. S., Schmidt, M. R., Sen, R., and Woodland, R. T. (2002). Naive B lymphocytes undergo homeostatic proliferation in response to B cell deficit. J Immunol 169, 67956805 .

Cadavid, D., Thomas, D. D., Crawley, R., and Barbour, A. G. (1994). Variability of a bacterial surface protein and disease expression in a possible mouse model of systemic Lyme borreliosis. J Exp Med 179, 631-642. 
Carter, R. H., and Fearon, D. T. (1989). Polymeric C3dg primes human B lymphocytes for proliferation induced by anti-IgM. J Immunol 143, 1755-1760.

Carter, R. H., Spycher, M. O., Ng, Y. C., Hoffman, R., and Fearon, D. T. (1988). Synergistic interaction between complement receptor type 2 and membrane $\operatorname{IgM}$ on B lymphocytes. J Immunol 141, 457-463.

Carvalho, T. L., Mota-Santos, T., Cumano, A., Demengeot, J., and Vieira, P. (2001). Arrested B lymphopoiesis and persistence of activated B cells in adult interleukin 7-/- mice. J Exp Med 194, 1141-1150.

Chelvarajan, R. L., Collins, S. M., Doubinskaia, I. E., Goes, S., Van Willigen, J., Flanagan, D., De Villiers, W. J., Bryson, J. S., and Bondada, S. (2004). Defective macrophage function in neonates and its impact on unresponsiveness of neonates to polysaccharide antigens. $\mathrm{J}$ Leukoc Biol 75, 982-994.

Chelvarajan, R. L., Collins, S. M., Van Willigen, J. M., and Bondada, S. (2005). The unresponsiveness of aged mice to polysaccharide antigens is a result of a defect in macrophage function. J Leukoc Biol 77, 503-512.

Chelvarajan, R. L., Gilbert, N. L., and Bondada, S. (1998). Neonatal murine B lymphocytes respond to polysaccharide antigens in the presence of IL-1 and IL-6. J Immunol 161, 3315-3324.

Chelvarajan, R. L., Liu, Y., Popa, D., Getchell, M. L., Getchell, T. V., Stromberg, A. J., and Bondada, S. (2006). Molecular basis of age-associated cytokine dysregulation in LPSstimulated macrophages. J Leukoc Biol 79, 1314-1327.

Chelvarajan, R. L., Raithatha, R., Venkataraman, C., Kaul, R., Han, S. S., Robertson, D. A., and Bondada, S. (1999). CpG oligodeoxynucleotides overcome the unresponsiveness of neonatal B cells to stimulation with the thymus-independent stimuli anti-IgM and TNPFicoll. Eur J Immunol 29, 2808-2818.

Chinen, J., and Shearer, W. T. (2002). Molecular virology and immunology of HIV infection. J Allergy Clin Immunol 110, 189-198.

Chong, Y., Ikematsu, H., Kikuchi, K., Yamamoto, M., Murata, M., Nishimura, M., Nabeshima, S., Kashiwagi, S., and Hayashi, J. (2004). Selective CD27+ (memory) B cell reduction and characteristic B cell alteration in drug-naive and HAART-treated HIV type 1infected patients. AIDS Res Hum Retroviruses 20, 219-226. 
Connolly, S. E., and Benach, J. L. (2001). The spirochetemia of murine relapsing fever is cleared by complement-independent bactericidal antibodies. J Immunol 167, 3029-3032.

Connolly, S. E., Thanassi, D. G., and Benach, J. L. (2004). Generation of a complementindependent bactericidal IgM against a relapsing fever Borrelia. J Immunol 172, 11911197.

Corley, R. B., Morehouse, E. M., and Ferguson, A. R. (2005). IgM accelerates affinity maturation. Scand J Immunol 62 Suppl 1, 55-61.

Couderc, J., Fevrier, M., Duquenne, C., Sourbier, P., and Liacopoulos, P. (1987). Xid mouse lymphocytes respond to TI- 2 antigens when co-stimulated by TI- 1 antigens or lymphokines. Immunology 61, 71-76.

de Vinuesa, C. G., Cook, M. C., Ball, J., Drew, M., Sunners, Y., Cascalho, M., Wabl, M., Klaus, G. G., and MacLennan, I. C. (2000). Germinal centers without T cells. J Exp Med 191, 485-494.

Dullforce, P., Sutton, D. C., and Heath, A. W. (1998). Enhancement of T cell-independent immune responses in vivo by CD40 antibodies. Nat Med 4, 88-91.

Ellmeier, W., Jung, S., Sunshine, M. J., Hatam, F., Xu, Y., Baltimore, D., Mano, H., and Littman, D. R. (2000). Severe B cell deficiency in mice lacking the tec kinase family members Tec and Btk. J Exp Med 192, 1611-1624.

Fagarasan, S., and Honjo, T. (2000). T-Independent immune response: new aspects of B cell biology. Science 290, 89-92.

Faili, A., Aoufouchi, S., Gueranger, Q., Zober, C., Leon, A., Bertocci, B., Weill, J. C., and Reynaud, C. A. (2002). AID-dependent somatic hypermutation occurs as a DNA singlestrand event in the BL2 cell line. Nat Immunol 3, 815-821.

Fehr, T., Naim, H. Y., Bachmann, M. F., Ochsenbein, A. F., Spielhofer, P., Bucher, E., Hengartner, H., Billeter, M. A., and Zinkernagel, R. M. (1998). T-cell independent IgM and enduring protective IgG antibodies induced by chimeric measles viruses. Nat Med 4, 945-948.

Feng, S. H., and Stein, K. E. (1991). VH gene family expression in mice with the xid defect. J Exp Med 174, 45-51.

Fikrig, E., Barthold, S. W., Chen, M., Grewal, I. S., Craft, J., and Flavell, R. A. (1996). Protective antibodies in murine Lyme disease arise independently of CD40 ligand. J Immunol 157, 1-3. 
Garcia-Monco, J. C., Miller, N. S., Backenson, P. B., Anda, P., and Benach, J. L. (1997). A mouse model of Borrelia meningitis after intradermal injection. Journal of Infectious Diseases 175, 1243-1245.

Gebbia, J. A., Monco, J. C., Degen, J. L., Bugge, T. H., and Benach, J. L. (1999). The plasminogen activation system enhances brain and heart invasion in murine relapsing fever borreliosis. J Clin Invest 103, 81-87.

Guinamard, R., Okigaki, M., Schlessinger, J., and Ravetch, J. V. (2000). Absence of marginal zone B cells in Pyk-2-deficient mice defines their role in the humoral response. Nat Immunol 1, 31-36.

Ha, S. A., Tsuji, M., Suzuki, K., Meek, B., Yasuda, N., Kaisho, T., and Fagarasan, S. (2006). Regulation of B1 cell migration by signals through Toll-like receptors. J Exp Med 203, 2541-2550.

Haas, K. M., Poe, J. C., Steeber, D. A., and Tedder, T. F. (2005). B-1a and B-1b cells exhibit distinct developmental requirements and have unique functional roles in innate and adaptive immunity to $S$. pneumoniae. Immunity $23,7-18$.

Hiernaux, J. R., Jones, J. M., Rudbach, J. A., Rollwagen, F., and Baker, P. J. (1983). Antibody response of immunodeficient (xid) $\mathrm{CBA} / \mathrm{N}$ mice to Escherichia coli 0113 lipopolysaccharide, a thymus-independent antigen. J Exp Med 157, 1197-1207.

Hopken, U. E., Achtman, A. H., Kruger, K., and Lipp, M. (2004). Distinct and overlapping roles of CXCR5 and CCR7 in B-1 cell homing and early immunity against bacterial pathogens. J Leukoc Biol 76, 709-718.

Hsu, M. C., Toellner, K. M., Vinuesa, C. G., and Maclennan, I. C. (2006). B cell clones that sustain long-term plasmablast growth in T-independent extrafollicular antibody responses. Proc Natl Acad Sci U S A 103, 5905-5910.

Janeway, C., Travers, P., Walport, M., and Shlomchik, M. (2004). Immunobiology: The immune system in health and disease, 6th edition edn (New York: Garland Publishing).

Jefferies, C. A., Doyle, S., Brunner, C., Dunne, A., Brint, E., Wietek, C., Walch, E., Wirth, T., and O'Neill, L. A. (2003). Bruton's tyrosine kinase is a Toll/interleukin-1 receptor domain-binding protein that participates in nuclear factor kappaB activation by Toll-like receptor 4. J Biol Chem 278, 26258-26264.

Jefferies, C. A., and O'Neill, L. A. (2004). Bruton's tyrosine kinase (Btk)-the critical tyrosine kinase in LPS signalling? Immunol Lett 92, 15-22. 
Kantor, A. B., Merrill, C. E., Herzenberg, L. A., and Hillson, J. L. (1997). An unbiased analysis of $\mathrm{V}(\mathrm{H})-\mathrm{D}-\mathrm{J}(\mathrm{H})$ sequences from B-1a, B-1b, and conventional B cells. J Immunol 158 , 1175-1186.

Kantor, A. B., Stall, A. M., Adams, S., Watanabe, K., and Herzenberg, L. A. (1995). De novo development and self-replenishment of B cells. Int Immunol 7, 55-68.

Kawai, T., Adachi, O., Ogawa, T., Takeda, K., and Akira, S. (1999). Unresponsiveness of MyD88-deficient mice to endotoxin. Immunity 11, 115-122.

Kelly, D. F., Moxon, E. R., and Pollard, A. J. (2004). Haemophilus influenzae type b conjugate vaccines. Immunology 113, 163-174.

Kelly, D. F., Pollard, A. J., and Moxon, E. R. (2005). Immunological memory: the role of B cells in long-term protection against invasive bacterial pathogens. JAMA 294, 3019-3023.

Khan, W. N., Alt, F. W., Gerstein, R. M., Malynn, B. A., Larsson, I., Rathbun, G., Davidson, L., Muller, S., Kantor, A. B., Herzenberg, L. A., and et al. (1995). Defective B cell development and function in Btk-deficient mice. Immunity 3, 283-299.

Khan, W. N., Nilsson, A., Mizoguchi, E., Castigli, E., Forsell, J., Bhan, A. K., Geha, R., Sideras, P., and Alt, F. W. (1997). Impaired B cell maturation in mice lacking Bruton's tyrosine kinase (Btk) and CD40. Int Immunol 9, 395-405.

Knoops, L., Louahed, J., and Renauld, J. C. (2004). IL-9-induced expansion of B-1b cells restores numbers but not function of B-1 lymphocytes in xid mice. J Immunol 172, 61016106.

Kruetzmann, S., Manuela Rosado, M., weber, H., Germing, U., Tournilhac, O., Peter, H. H., Berner, R., Peters, A., Boehm, T., Plebani, A., et al. (2003). Human immunoglobulin M memory B cells controlling Streptococcus pneumoniae infections are generated in the spleen. J Exp Med 197, 939-945.

Kurt-Jones, E. A., Popova, L., Kwinn, L., Haynes, L. M., Jones, L. P., Tripp, R. A., Walsh, E. E., Freeman, M. W., Golenbock, D. T., Anderson, L. J., and Finberg, R. W. (2000). Pattern recognition receptors TLR4 and CD14 mediate response to respiratory syncytial virus. Nat Immunol 1, 398-401.

Landers, C. D., Chelvarajan, R. L., and Bondada, S. (2005). The role of B cells and accessory cells in the neonatal response to TI-2 antigens. Immunol Res 31, 25-36. 
Leadbetter, E. A., Rifkin, I. R., Hohlbaum, A. M., Beaudette, B. C., Shlomchik, M. J., and Marshak-Rothstein, A. (2002). Chromatin-IgG complexes activate B cells by dual engagement of IgM and Toll-like receptors. Nature 416, 603-607.

Lesinski, G. B., and Westerink, M. A. (2001). Novel vaccine strategies to T-independent antigens. J Microbiol Methods 47, 135-149.

MacLennan, I. C., Garcia de Vinuesa, C., and Casamayor-Palleja, M. (2000). B-cell memory and the persistence of antibody responses. Philos Trans R Soc Lond Biol Sci 355, 345-350.

Maizels, N., and Bothwell, A. (1985). The T-cell-independent immune response to the hapten NP uses a large repertoire of heavy chain genes. Cell 43, 715-720.

Maizels, N., Lau, J. C., Blier, P. R., and Bothwell, A. (1988). The T-cell independent antigen, NP-ficoll, primes for a high affinity IgM anti-NP response. Mol Immunol 25, 1277-1282.

Malley, R., Henneke, P., Morse, S. C., Cieslewicz, M. J., Lipsitch, M., Thompson, C. M., KurtJones, E., Paton, J. C., Wessels, M. R., and Golenbock, D. T. (2003). Recognition of pneumolysin by Toll-like receptor 4 confers resistance to pneumococcal infection. Proc Natl Acad Sci U S A 100, 1966-1971.

Martin, F., and Kearney, J. F. (2000). B-cell subsets and the mature preimmune repertoire. Marginal zone and B1 B cells as part of a "natural immune memory". Immunol Rev 175, 70-79.

Martin, F., and Kearney, J. F. (2001). B1 cells: similarities and differences with other B cell subsets. Curr Opin Immunol 13, 195-201.

Martin, F., Oliver, A. M., and Kearney, J. F. (2001). Marginal zone and B1 B cells unite in the early response against $\mathrm{T}$ - independent blood-borne particulate antigens. Immunity 14 , 617-629.

McHeyzer-Williams, L. J., Driver, D. J., and McHeyzer-Williams, M. G. (2001). Germinal center reaction. Curr Opin Hematol 8, 52-59.

McHeyzer-Williams, M. G. (2003). B cells as effectors. Curr Opin Immunol 15, 354-361.

Mizuno, T., and Rothstein, T. L. (2003). Cutting edge: CD40 engagement eliminates the need for Bruton's tyrosine kinase in B cell receptor signaling for NF-kappa B. J Immunol 170, 2806-2810.

Mizuno, T., and Rothstein, T. L. (2005). B cell receptor (BCR) cross-talk: CD40 engagement creates an alternate pathway for BCR signaling that activates I kappa B kinase/I kappa B 
alpha/NF-kappa B without the need for PI3K and phospholipase C gamma. J Immunol 174, 6062-6070.

Montecino-Rodriguez, E., and Dorshkind, K. (2006). New perspectives in B-1 B cell development and function. Trends Immunol 27, 428-433.

Montecino-Rodriguez, E., Leathers, H., and Dorshkind, K. (2006). Identification of a B-1 B cellspecified progenitor. Nat Immunol 7, 293-301.

Mosier, D. E., Scher, I., and Paul, W. E. (1976). In vitro responses of CBA/N mice: spleen cells of mice with an $\mathrm{X}$-linked defect that precludes immune responses to several thymusindependent antigens can respond to TNP-lipopolysaccharide. J Immunol 117, 13631369.

Mosier, D. E., Zaldivar, N. M., Goldings, E., Mond, J., Scher, I., and Paul, W. E. (1977). Formation of antibody in the newborn mouse: study of T-cell-independent antibody response. J Infect Dis 136 Suppl, S14-19.

Muller, G., Hopken, U. E., and Lipp, M. (2003). The impact of CCR7 and CXCR5 on lymphoid organ development and systemic immunity. Immunol Rev 195, 117-135.

Muramatsu, M., Kinoshita, S., Fagarasan, S., Yamada, Y., Shinkai, Y., and Honjo, T. (2000). Class switch recombination and hypermutation require Activation-induced cytidine demainase (AID), a potential RNA editing enzyme. Cell 102, 553-563.

Nagai, Y., Akashi, S., Nagafuku, M., Ogata, M., Iwakura, Y., Akira, S., Kitamura, T., Kosugi, A., Kimoto, M., and Miyake, K. (2002). Essential role of MD-2 in LPS responsiveness and TLR4 distribution. Nat Immunol 3, 667-672.

Obukhanych, T. V., and Nussenzweig, M. C. (2006). T-independent type II immune responses generate memory B cells. J Exp Med 203, 305-310.

Ochsenbein, A. F., Pinschewer, D. D., Odermatt, B., Carroll, M. C., Hengartner, H., and Zinkernagel, R. M. (1999). Protective T cell-independent antiviral antibody responses are dependent on complement. J Exp Med 190, 1165-1174.

Pinschewer, D. D., Ochsenbein, A. F., Satterthwaite, A. B., Witte, O. N., Hengartner, H., and Zinkernagel, R. M. (1999). A Btk transgene restores the antiviral TI-2 antibody responses of xid mice in a dose-dependent fashion. Eur J Immunol 29, 2981-2987.

Satterthwaite, A. B., Cheroutre, H., Khan, W. N., Sideras, P., and Witte, O. N. (1997). Btk dosage determines sensitivity to B cell antigen receptor cross-linking. Proc Natl Acad Sci U S A 94, 13152-13157. 
Scher, I., Steinberg, A. D., Berning, A. K., and Paul, W. E. (1975). X-linked B-lymphocyte immune defect in CBA/N mice. II. Studies of the mechanisms underlying the immune defect. J Exp Med 142, 637-650.

Schnare, M., Barton, G. M., Holt, A. C., Takeda, K., Akira, S., and Medzhitov, R. (2001). Tolllike receptors control activation of adaptive immune responses. Nat Immunol 2, 947-950.

Schroder, N. W., Opitz, B., Lamping, N., Michelsen, K. S., Zahringer, U., Gobel, U. B., and Schumann, R. R. (2000). Involvement of lipopolysaccharide binding protein, CD14, and Toll-like receptors in the initiation of innate immune responses by Treponema glycolipids. J Immunol 165, 2683-2693.

Scorpio, A., Chabot, D. J., Day, W. A., O'Brien D, K., Vietri, N. J., Itoh, Y., Mohamadzadeh, M., and Friedlander, A. M. (2007). Poly-gamma-glutamate capsule-degrading enzyme treatment enhances phagocytosis and killing of encapsulated Bacillus anthracis. Antimicrob Agents Chemother 51, 215-222.

Selinka, H. C., and Bosing-Schneider, R. (1988). xid mice fail to express an anti-dextran immune response but carry alpha(1-3)dextran-specific lymphocytes in their potential repertoire. Eur J Immunol 18, 1727-1732.

Shang, E. S., Skare, J. T., Exner, M. M., Blanco, D. R., Kagan, B. L., Miller, J. N., and Lovett, M. A. (1998). Isolation and characterization of the outer membrane of Borrelia hermsii. Infect Immun 66, 1082-1091.

Snapper, C. M., Rosas, F. R., Moorman, M. A., and Mond, J. J. (1997). Restoration of T cellindependent type 2 induction of Ig secretion by neonatal B cells in vitro. J Immunol 158, 2731-2735.

Southern, P. M., Jr., and Sanford, J. P. (1969). Relapsing Fever-A clinical and microbiological review. Medicine 48, 129-149.

Stall, A. M., Adams, S., Herzenberg, L. A., and Kantor, A. B. (1992). Characteristics and development of the murine B-1b (Ly-1 B sister) cell population. Ann N Y Acad Sci 651, $33-43$.

Szomolanyi-Tsuda, E., Brien, J. D., Dorgan, J. E., Garcea, R. L., Woodland, R. T., and Welsh, R. M. (2001). Antiviral T-cell-independent type 2 antibody responses induced in vivo in the absence of T and NK cells. Virology 280, 160-168. 
Szomolanyi-Tsuda, E., Seedhom, M. O., Carroll, M. C., and Garcea, R. L. (2006). T cellindependent and $\mathrm{T}$ cell-dependent immunoglobulin $\mathrm{G}$ responses to polyomavirus infection are impaired in complement receptor 2-deficient mice. Virology 352, 52-60.

Szomolanyi-Tsuda, E., and Welsh, R. M. (1998). T-cell-independent antiviral antibody responses. Curr Opin Immunol 10, 431-435.

Takeda, K., and Akira, S. (2005). Toll-like receptors in innate immunity. Int Immunol 17, 1-14.

Tarlinton, D. (2006). B-cell memory: are subsets necessary? Nat Rev Immunol 6, 785-790.

Thomas, J. D., Sideras, P., Smith, C. I. E., Vorechovsky, I., Chapman, V., and Paul, W. E. (1993). Colocalization of X-linked agammaglobulinemia and X-linked Immunodeficiency genes. Science 261, 355-358.

Toellner, K. M., Jenkinson, W. E., Taylor, D. R., Khan, M., Sze, D. M., Sansom, D. M., Vinuesa, C. G., and MacLennan, I. C. (2002). Low-level hypermutation in T cellindependent germinal centers compared with high mutation rates associated with $\mathrm{T}$ celldependent germinal centers. J Exp Med 195, 383-389.

Tornberg, U. C., and Holmberg, D. (1995). B-1a, B-1b and B-2 B cells display unique VHDJH repertoires formed at different stages of ontogeny and under different selection pressures. EMBO J 14, 1680-1689.

Toyama, H., Okada, S., Hatano, M., Takahashi, Y., Takeda, N., Ichii, H., Takemori, T., Kuroda, Y., and Tokuhisa, T. (2002). Memory B cells without somatic hypermutation are generated from Bcl6-deficient B cells. Immunity 17, 329-339.

Tung, J. W., Mrazek, M. D., Yang, Y., Herzenberg, L. A., and Herzenberg, L. A. (2006). Phenotypically distinct B cell development pathways map to the three B cell lineages in the mouse. Proc Natl Acad Sci U S A 103, 6293-6298.

Vink, A., Warnier, G., Brombacher, F., and Renauld, J. C. (1999). Interleukin 9-induced in vivo expansion of the B-1 lymphocyte population. J Exp Med 189, 1413-1423.

Vinuesa, C. G., Sunners, Y., Pongracz, J., Ball, J., Toellner, K. M., Taylor, D., MacLennan, I. C., and Cook, M. C. (2001). Tracking the response of Xid B cells in vivo: TI-2 antigen induces migration and proliferation but Btk is essential for terminal differentiation. Eur $\mathrm{J}$ Immunol 31, 1340-1350.

Vos, Q., Lees, A., Wu, Z., Snapper, C. M., and Mond, J. J. (2000). B-cell activation by T-cellindependent type 2 antigens as an integral part of the humoral immune response to pathogenic microorganisms. Immunol Rev 176, 154-170. 
Wang, T. T., and Lucas, A. H. (2004). The capsule of Bacillus anthracis behaves as a thymusindependent type 2 antigen. Infect Immun 72, 5460-5463.

Watanabe, N., Ikuta, K., Fagarasan, S., Yazumi, S., Chiba, T., and Honjo, T. (2000). Migration and differentiation of autoreactive B-1 cells induced by activated gamma/delta $\mathrm{T}$ cells in anti-erythrocyte immunoglobulin transgenic mice. J Exp Med 192, 1577-1586.

Weller, S., Faili, A., Garcia, C., Braun, M. C., Le Deist, F. F., de Saint Basile, G. G., Hermine, O., Fischer, A., Reynaud, C. A., and Weill, J. C. (2001). CD40-CD40L independent Ig gene hypermutation suggests a second B cell diversification pathway in humans. Proc Natl Acad Sci U S A 98, 1166-1170.

Woodland, R. T., and Schmidt, M. R. (2005). Homeostatic proliferation of B cells. Semin Immunol 17, 209-217.

Woodland, R. T., Schmidt, M. R., Korsmeyer, S. J., and Gravel, K. A. (1996). Regulation of B cell survival in xid mice by the proto-oncogene bcl-2. J Immunol 156, 2143-2154.

Yan, S. R., Byers, D. M., and Bortolussi, R. (2004a). Role of protein tyrosine kinase p53/56lyn in diminished lipopolysaccharide priming of formylmethionylleucyl- phenylalanineinduced superoxide production in human newborn neutrophils. Infect Immun 72, 64556462.

Yan, S. R., Qing, G., Byers, D. M., Stadnyk, A. W., Al-Hertani, W., and Bortolussi, R. (2004b). Role of MyD88 in diminished tumor necrosis factor alpha production by newborn mononuclear cells in response to lipopolysaccharide. Infect Immun 72, 1223-1229.

Yokota, M., Morshed, M. G., Nakazawa, T., and Konishi, H. (1997). Protective activity of Borrelia duttonii-specific immunoglobulin subclasses in mice. J Med Microbiol 46, 675680.

Yu, P. W., Tabuchi, R. S., Kato, R. M., Astrakhan, A., Humblet-Baron, S., Kipp, K., Chae, K., Ellmeier, W., Witte, O. N., and Rawlings, D. J. (2004). Sustained correction of B-cell development and function in a murine model of X-linked agammaglobulinemia (XLA) using retroviral-mediated gene transfer. Blood 104, 1281-1290.

Zandvoort, A., Lodewijk, M. E., de Boer, N. K., Dammers, P. M., Kroese, F. G., and Timens, W. (2001). CD27 expression in the human splenic marginal zone: the infant marginal zone is populated by naive B cells. Tissue Antigens 58, 234-242. 
Zandvoort, A., and Timens, W. (2002). The dual function of the splenic marginal zone: essential for initiation of anti-TI-2 responses but also vital in the general first-line defense against blood-borne antigens. Clin Exp Immunol 130, 4-11.

Zinkernagel, R. M. (2000). What is missing in immunology to understand immunity? Nat Immunol 1, 181-185. 
Figure legends

\section{Figure 1.}

A. Expansion of the B1b cell population in B. hermsii-infected mice. PerC cells of uninfected or four-week post-infected xid (CBA/N) mice were harvested and stained with antibodies specific for IgM, IgD and Mac1 or CD5 and analyzed by flow cytometry (Alugupalli et al., 2003a). All B cells were first identified by IgD and IgM dual positivity (plots not shown) and were further resolved as B1 (i.e. B1a + B1b) and B1a populations by Mac1 and CD5 positivity, respectively. The percent frequency values of B1 and B1a cells, among the all PerC cells are indicated within the plots. The frequency of B1b cells was inferred from values obtained from the subtraction of the $\%$ of B1a $\left(\mathrm{CD}^{+}\right)$cells from the $\%$ of all B1 cells $\left(\mathrm{Mac}^{+}\right)$. Data were generated by analyzing a minimum of 20,000 cells and are representative of four separate experiments. $5 \%$ contour plots are shown.

B. Persistent expansion of B1b lymphocytes in $\boldsymbol{B}$. hermsii-infected mice. PerC cells of uninfected or B. hermsii infected xid (CBA/N) mice at the indicated days post-infection (dpi) were harvested and frequencies of B1b, B1a and B2 subsets were determined by flow cytometry. The absolute cell counts of $\mathrm{B} 1 \mathrm{~b}\left(\operatorname{IgM}^{\text {high }}, \operatorname{IgD}^{\text {low }}, \mathrm{Mac1}^{+}\right.$and $\left.\mathrm{CD} 5\right), \mathrm{B} 1 \mathrm{a}\left(\operatorname{IgM}{ }^{\text {high }}, \operatorname{IgD}^{\text {low }}, \mathrm{Mac1}^{+}\right.$and $\left.\mathrm{CD}^{+}\right)$and $\mathrm{B} 2\left(\mathrm{IgD}^{\text {high }}, \operatorname{IgM}^{\text {low }}, \mathrm{Mac1}^{-}\right)$were calculated as a product of their frequency and the PerC cell yield. The mean \pm SD values of respective subsets of three mice at the indicated dpi are given. Significant expansion of B1b cells occurred in infected xid mice $(* *, p<0.002)$

(Alugupalli et al., 2004).

C. Expansion of B1b cells is T cell-independent. PerC cells of naïve or convalescent (40 dpi) TCR- $\beta \mathrm{x} \delta^{--}$mice were harvested and stained with $\operatorname{IgM}, \operatorname{IgD}$ and Mac1 or CD5 and the absolute cell numbers of B1b, B1a and B2 were determined. The mean \pm SD values of five mice are shown. Significant expansion of B1b cells occurred in infected TCR- $\beta \times \delta^{-/}$mice $(* *, p<0.002)$ (Alugupalli et al., 2004).

D. Rapid egress of B1b cells from the peritoneal cavity (PerC) during B. hermsii infection. Wildtype mice were infected intravenously with $5 \times 10^{4}$ B.hermsii strain DAH-p1. On each of the indicated days post-infection, three mice were sacrificed. Bacteremia and frequency of B1b cells in the PerC were measured by microscopic counting and flow cytometry, respectively.

Deleted: one

Deleted: mouse

Deleted: as 
Significant reduction of B $1 \mathrm{~b}$ cells occurred during the acute phase of the bacteremia (i.e. 2 and 3 dpi) $(*, p<0.05)$

Figure 2. Kinetics of the B. hermsii-specific IgM response in various knockout mice.

A. Wildtype ( $\mathrm{n}=3)$, T cell-deficient (TCR- $\left.\beta \times \delta^{-{ }_{-}} ; \mathrm{n}=3\right), \mathrm{C}^{-{ }_{-}}(\mathrm{n}=5)$ or $\mathrm{IL}=1 \mathrm{R}^{-{ }_{-}}(\mathrm{n}=5)$ mice; $\mathbf{B}$. Wildtype ( $n=3)$ or mice deficient in either Btk (Btk KO; $n=3)$ or MyD88 (MyD88 KO; n=3) or both (Btk x MyD88 KO; $\mathrm{n}=4$ ) were infected intravenously with $5 \times 10^{4}$ B.hermsii strain DAHp1. B. hermsii-specific IgM responses in the blood on the indicated days post-infection were measured by ELISA and mean \pm SD values are shown (Alugupalli et al., 2007).

Figure 3. A model for the efficient protection conferred by B1b cells to pathogens in convalescent mice.

Upon infection or exposure to a specific T cell-independent antigen, B1b cells of varying affinities generate a short-lived IgM response. In this primary response, a division of labor by appropriate MZ B and/or B1a subsets (not shown in the figure) may also contribute to the IgM response. While a significant fraction of this IgM may recognize the pathogens, only some of this response is protective during primary infection. On the other hand, a subset of B1b cells driven by specific antigens expand with the help of a $\mathrm{T}$ cell-independent co-stimulatory signal (see Sect. 6), persist in convalescent mice with higher frequency, and maintain a quiescent state in terms of their further differentiation into plasma cells. Such B1b cells acquire a functional memory B1b cell phenotype. Compared to their naïve counterparts, the ability of memory B1b cells to mount a heightened IgM response, upon antigen exposure, results in efficient protection from re-infection. Factors that may contribute to this rapid response include an altered transcriptomic profile and surface expression of other signaling receptors. Since AID can be induced by BCR cross-linking and TLR stimulation, IgM secreting B1b cells could also switch to other isotypes, such as IgG3. 